\title{
Inheritance of Vernalization Requirement in Carrot
}

\author{
María S. Alessandro and Claudio R. Galmarini ${ }^{1}$ \\ Estación Experimental Agropecuaria La Consulta, Instituto Nacional de Tecnología \\ Agropecuaria, Ex Ruta 40, km 96, La Consulta, Mendoza, Argentina, PC. 5567, CC 8
}

AdDitional IndeX words. Daucus carota, flowering, annual, biennial, juvenility, sowing date

\begin{abstract}
Carrot (Daucus carota $\mathbf{L}$.) is a cool-season vegetable normally classified as a biennial or winter annual species, requiring vernalization to induce flowering. Nevertheless, some cultivars adapted to warmer climates require less vernalization and can be classified as early flowering or annual. The genetic control of this phenotypic difference has not been previously studied in carrot. The authors evaluated $\mathrm{F}_{1}, \mathrm{~F}_{2}$, and $\mathrm{BC}_{1}$ progenies of an intercross between the early-flowering carrot ('Criolla INTA') and a late-flowering biennial carrot. $F_{1}$ progenies were completely annual. Observed segregation ratios in the $\mathrm{F}_{2}$ and $\mathrm{BC}_{1}$ families were not significantly different from expected segregation ratios under the hypothesis of a single dominant gene conditioning the early-flowering habit. The authors conclude that annual habit is dominant over biennial and is a monogenic character.
\end{abstract}

In almost all crop species we know as biennials, early flowering or annual plants are usually found. These crops include carrot, beet [Beta vulgaris L. var. crassa (Alef) J.Helm], sugar beet (Beta vulgaris L. var. saccharifera Alef.), cabbage (Brassica oleracea L. var. capitata L.), turnip (Brassica rapa $\mathrm{L}$.), and clover (Trifolium repens $\mathrm{L}$.). The occurrence of annuals causes considerable economic loss to the grower. Carrot is normally classified as a biennial species that requires vernalization to induce flowering. During the first year it produces a basal rosette of leaves and stores carbohydrates in its hypertrophic root (Whitaker et al., 1970). The stage of growth when carrot seedlings are not responsive to lowtemperature vernalization is known as juvenility. This condition usually ends when carrot plants have initiated 8 to 12 leaves, and storage roots are larger than 4 to $8 \mathrm{~mm}$ in diameter (Atherton et al., 1990; Galmarini and Della Gaspera, 1996; Galmarini et al., 1992; Lona and Crnko, 1967). After a vernalization period, with temperatures between 0 and $10{ }^{\circ} \mathrm{C}$, and long days, floral stem elongation and flowering are induced (Atherton and Basher, 1984; Dickson and Peterson, 1958; Sakr and Thompson, 1942). Carrot roots quickly become very lignified after vernalization, even before the floral stalk elongates, so that the initiation of flowering results in a complete loss of commercial value (Rubatzky et al., 1999).

The level of response to cold treatments is cultivar dependent. Late-flowering cultivars require $\approx 11$ to 12 weeks at $5{ }^{\circ} \mathrm{C}$ to be permanently vernalized (Atherton et al., 1990; Hiller and Kelly, 1979; Rubatzky et al., 1999). Early-flowering cultivars, as shown by Dias Tagliacozzo and Valio (1994) and suggested by Galmarini and Della Gaspera (1996), require shorter vernalization periods (1-4 weeks) than late-flowering cultivars. 'Criolla INTA' is a cultivar that can be classified as annual or early flowering because it has short vernalization requirements; Galmarini and Della Gaspera (1996) reported that this cultivar has the same juvenile period as the cultivar Flakkee (biennial), suggesting that its annual behavior results from a lower cold requirement after juvenility rather than a shorter juvenile period.

At La Consulta, Mendoza, Argentina (lat. $33^{\circ} 42^{\prime} \mathrm{S}$, long. $69^{\circ} 04^{\prime} \mathrm{W}$ ), the flowering habit defines the sowing time, depending on whether the growers want to produce seed or root crops

Received for publication 13 Sept. 2006. Accepted for publication 27 Jan. 2007. ${ }^{1}$ Corresponding author. E-mail: crgalmarini@laconsulta.inta.gov.ar.
(Oliva, 1987). For seed production, using the seed-to-seed method, late-flowering cultivars must be sown early in the summer (January) to flower late the following spring (November), whereas the early-flowering cultivars can be sown in the summer, autumn and early winter (from January-July), and they are able to flower the same year of sowing (Astorquizaga et al., 2004; Galmarini and Della Gaspera, 1996).

The genetics of vernalization response and flowering habit have been studied in several biennial species, including the Brassica species, B. napus L., B. rapa, and B. oleracea (Bagget and Kean, 1989; Ferreira et al., 1995). In B. oleracea the annual habit is clearly dominant and seems to be controlled by several factors, and the inheritance pattern for flowering behavior depends on the particular parents used (Bagget and Kean, 1989; Walkof, 1963). There are several studies of the physiological bases of vernalization response in carrot (e.g., Atherton et al., 1990), but there are no studies about the genetics of this trait.

The current work was designed to study the genetic control of vernalization response in carrot by evaluating progeny of crosses between early- and late-flowering cultivars.

\section{Materials and Methods}

Four individuals plants of 'Criolla INTA' (early-flowering parents: E1, E2, E3, and E4) were intercrossed with plants of two male-sterile biennial lines (late-flowering parents: L1 and L2), from the Instituto Nacional de Tecnología Agropecuaria (INTA) breeding program to generate four $\mathrm{F}_{1}$ families $(\mathrm{L} 1 \times \mathrm{E} 1$, $\mathrm{L} 2 \times \mathrm{E} 2, \mathrm{~L} 2 \times \mathrm{E} 3$, and $\mathrm{L} 2 \times \mathrm{E} 4)$ that were evaluated during the first year. 'Criolla INTA' is a cultivar obtained by mass selection of annual local carrot populations of Argentina. It has cylindrical roots, a blunt end, an orange cortex and core, and its average root length is 12 to $15 \mathrm{~cm}$. 'Criolla INTA' often restores fertility to cytoplasmic male-sterile hybrids, and several male-fertile $F_{1}$ plants were noted. Two $F_{2}$ families derived from self-pollinated individual $\mathrm{F}_{1}$ plants from $\mathrm{L} 2 \times \mathrm{E} 2$, two backcross families derived from $(\mathrm{L} 1 \times \mathrm{E} 1) \times \mathrm{E} 1$ and two from $(\mathrm{L} 2 \times \mathrm{E} 2) \times \mathrm{E} 2$, were evaluated the second year (Table 1$)$.

First year. The parents and $F_{1}$ were direct seeded in the field at La Consulta, Mendoza, Argentina (lat. $33^{\circ} 42^{\prime} \mathrm{S}$, long. $69^{\circ} 04^{\prime} \mathrm{W}$ ), on three different sowing dates (3 Mar., 20 Apr., and 6 June 2004) to ensure they received a range of exposures to low 
Table 1. Segregating families used in this study of the inheritance of vernalization requirement in carrot.

\begin{tabular}{llcl}
\hline Progeny pedigree $^{\mathrm{z}}$ & Generation $^{\mathrm{y}}$ & $\begin{array}{c}\text { Families } \\
\text { (no.) }\end{array}$ & $\begin{array}{c}\text { Family } \\
\text { identification }\end{array}$ \\
\hline$(\mathrm{L} 1 \times \mathrm{E} 1) \times \mathrm{E} 1$ & $\mathrm{BC}_{1} \mathrm{P} 2$ & 2 & $\mathrm{BC}_{1} \mathrm{a}, \mathrm{BC}_{1} \mathrm{~b}$ \\
$\mathrm{~L} 2 \times \mathrm{E} 2$ & $\mathrm{~F}_{2}$ & 2 & $\mathrm{~F}_{2} \mathrm{a}, \mathrm{F}_{2} \mathrm{~b}$ \\
$(\mathrm{~L} 2 \times \mathrm{E} 2) \times \mathrm{E} 2$ & $\mathrm{BC}_{1} \mathrm{P} 2$ & 2 & $\mathrm{BC}_{1} \mathrm{c}, \mathrm{BC}_{1} \mathrm{~d}$
\end{tabular}

${ }^{\mathrm{z}} \mathrm{L} 1$ and L2, late-flowering parents; E1 and E2, early flowering parents. ${ }^{\mathrm{y}} \mathrm{P} 2$, early-flowering parent.

Table 2. Monthly average minimum, maximum, and mean temperatures May through October in 2004 and 2005 at $\mathrm{La}$ Consulta, Mendoza, Argentina.

\begin{tabular}{lrrrcrr}
\hline & May & June & July & August & September & October \\
\cline { 2 - 7 } Year & \multicolumn{6}{c}{ Temperature $\left({ }^{\circ} \mathrm{C}\right)$} \\
\hline 2004 & & & & & & \\
Minimum & 1.8 & -0.6 & -1.3 & 0.9 & 3.7 & 6.5 \\
Maximum & 13.4 & 15.8 & 13.4 & 16.1 & 20.1 & 23.9 \\
Mean & 7.6 & 7.6 & 6.0 & 8.5 & 11.9 & 15.2 \\
2005 & & & & & & \\
Minimum & 0.4 & 0.3 & -1.0 & 0.9 & 2.4 & 5.3 \\
Maximum & 17.7 & 13.5 & 14.7 & 14.6 & 17.1 & 23.3 \\
Mean & 9.1 & 6.9 & 6.9 & 7.8 & 9.8 & 14.3 \\
\hline
\end{tabular}

temperatures (Table 2). For each sowing date, a randomized block design with three repetitions was used. Each plot had 20 plants on average, seeded in rows $0.8 \mathrm{~m}$ apart, with plants spaced $0.25 \mathrm{~m}$ apart within rows.

Once per week each plot was evaluated. Individual plants were scored as being vegetative until the first floral internode elongated. This was soon followed by the appearance of floral primordia. For each plot, the following six dates were noted: when $50 \%$ of the plants had their first floral stem internode elongated (Fig. 1A); when $100 \%$ of the plants had their first floral stem internode elongated, when $50 \%$ of plants had floral primordia in the primary umbel, and when $100 \%$ of plants had floral primordia in the primary umbel (Fig. 1B); and when 50\% of the plants displayed flowering in primary umbel and when $100 \%$ of the plants displayed flowering in primary umbel (Fig. $1 \mathrm{C})$. With these data, the proportion of flowering plants, weeks from sowing to first elongated internode, weeks to primordia
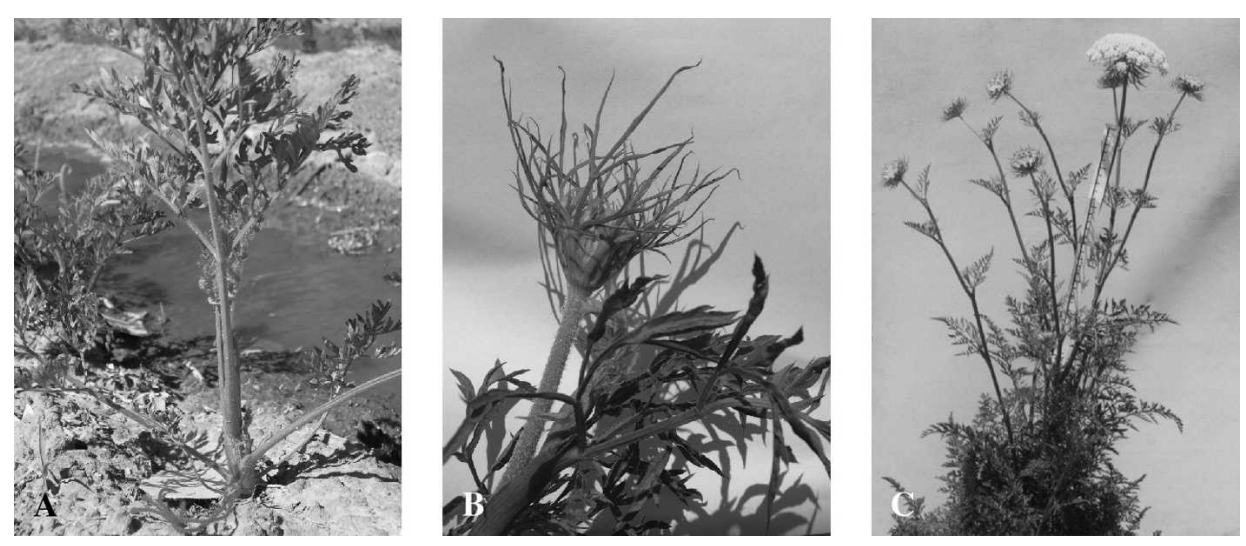

Fig. 1. Phenological stages of carrot flowering plants. (A) First floral stem internode elongated. (B) Floral primordial. (C) Plant with flowering primary umbel.

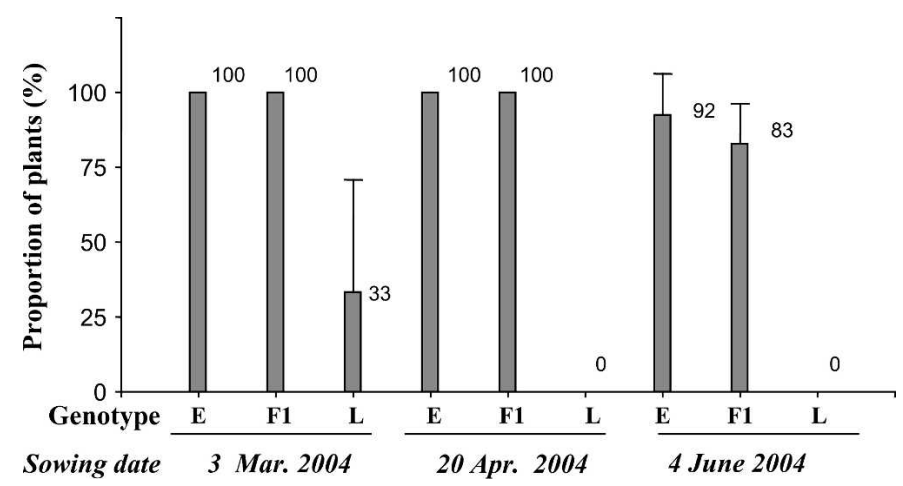

Fig. 2. Proportion of flowering carrot plants at three sowing dates for earlyflowering parents (E), late-flowering parents (L), and their crosses (F1) during the first year. For each category the mean and SD are presented.

appearance, and weeks to flowering were calculated. Analysis of variance and mean separation were carried out for each sowing date.

SECOND Year. $F_{2}$ families, backcross families, $F_{1}$, and parents were sown on 4 May 2005 in the field at La Consulta, Mendoza, Argentina. A second sowing was carried out on 14 June 2005 including $F_{2}$ and their respective parents. On the first sowing date, the following populations sizes were evaluated: 280 plants from $\mathrm{F}_{2} \mathrm{a}, 203$ plants from $\mathrm{F}_{2} \mathrm{~b}, 61$ plants from $\mathrm{BC}_{1} \mathrm{a}$, 66 plants from $\mathrm{BC}_{1} \mathrm{~b}, 201$ plants from $\mathrm{BC}_{1} \mathrm{c}$, and 51 plants from $\mathrm{BC}_{1}$ d. On the second sowing date, 61 plants from $\mathrm{F}_{2} \mathrm{a}$ and 51 plants from $\mathrm{F}_{2} \mathrm{~b}$ were evaluated. Individual plants and populations were scored as done the first year. Percentage of flowered plants for each population, and weeks from sowing date to first floral stem internode elongated for individual plants were calculated. Goodness-of-fit was evaluated by comparing observed and expected data with single-df $\chi^{2}$ calculations.

\section{Results}

For all three sowing dates during the first year, all plants of the early-flowering parents and the $F_{1}$ flowered, whereas only one of the late-flowering parents (L2) flowered in the first sowing date. No late-flowering plants flowered in the later sowing dates (Figs. 2 and 3).

The flowering cycle of the $F_{1}$ progenies was the same as the early-flowering parents. Although the early-flowering parents and F1 showed a shorter cycle when the sowing date was delayed, the lateflowering parents did not flower at all (Fig. 3).

During the second year, all the individual plants evaluated from the early-flowering parents (E1 and E2) flowered on the first sowing date (4 May 2005), whereas none of the L1 plants (late-flowering parent) and only $12 \%$ of L 2 plants flowered. From the $\mathrm{F}_{1}$ populations, $100 \%$ of $\mathrm{L} 1 \times \mathrm{E} 1$ plants and $88 \%$ of $\mathrm{L} 2 \times \mathrm{E} 2$ plants flowered. The distribution of flowered and nonflowered plants in segregating generations supported the hypothesis that a single dominant gene controlled the early-flowering habit (Fig. 4 and 


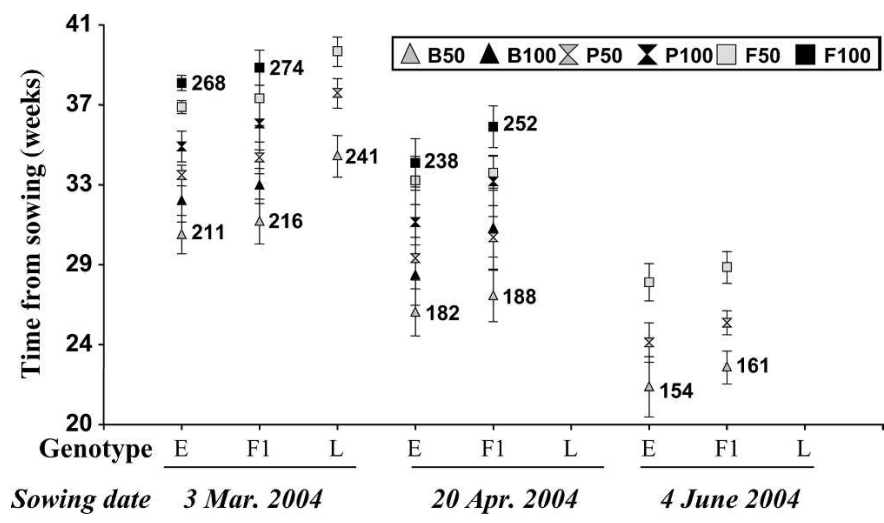

Fig. 3. Evolution of carrot flowering at different sowing dates during the first year. Weeks from sowing to $50 \%$ bolted plants (B50), 100\% bolted plants (B100), 50\% of plants with floral primordia (P50), 100\% of plants with floral primordia (P100), 50\% of flowering plants (F50), and $100 \%$ of flowering plants (F100) are presented for early-flowering parents (E), late-flowering parents (L), and their crosses (F1) at each sowing date. For each category the mean and SD are presented. Values after B50 and F100 categories are average values for days after sowing for these two categories. Flowering did not reach completion for L with the 3 Mar. sowing date or for E and F1 for the 4 June sowing date. No flowering was observed for L on either the $20 \mathrm{Apr}$. or 4 June sowing dates, so no values are presented.

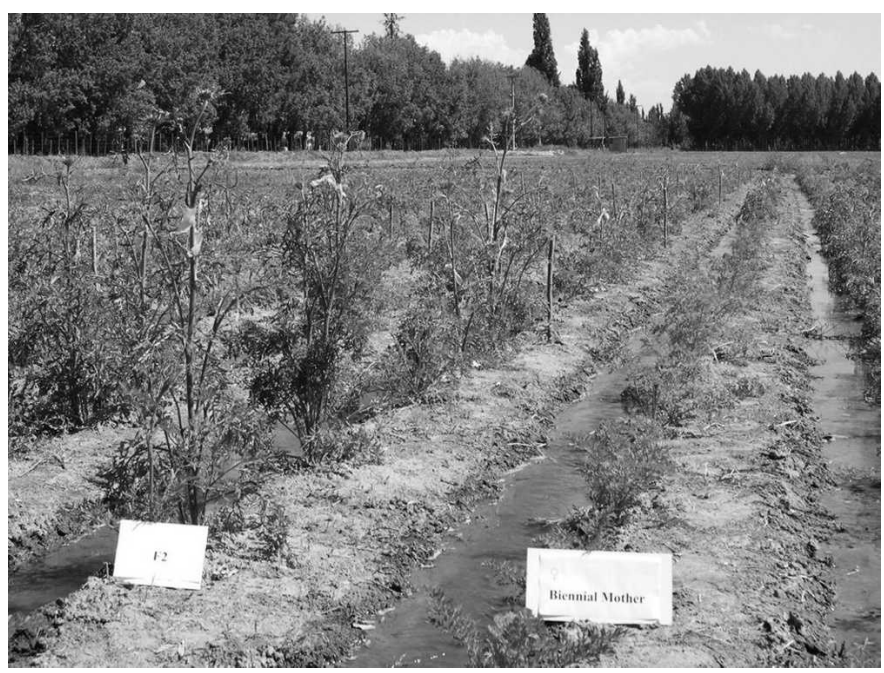

Fig. 4. Photograph of $\mathrm{F}_{2} \mathrm{~b}$ family (left) and its biennial mother L2 (right) on 10 Nov. 2005.
Table 3). Segregation ratios in the $\mathrm{F}_{2}$ and $\mathrm{BC}_{1}$ families were not significantly different from that expected under the hypothesis of a single dominant gene conditioning the early-flowering habit (Table 3).

On the second sowing date (14 June 2005), 100\% of E2 plants flowered whereas $6 \%$ of L2 plants flowered. For the $\mathrm{F}_{2}$ families there was higher variability for the distribution of flowered and nonflowered plants; only $63.9 \%$ of $\mathrm{F}_{2}$ a plants flowered whereas $80.4 \%$ of $\mathrm{F}_{2}$ b plants flowered.

The highest proportion of plants of the $\mathrm{F}_{1}$ generation $(\mathrm{L} 1 \times$ $\mathrm{E} 1$ and L2 $\times \mathrm{E} 2$ ) on the first sowing date bolted 1 week later than their annual parents (E1 and $\mathrm{E} 2)$, whereas for the $\mathrm{BC}_{1}$ generation, the date when the highest proportion of plants bolted was the same $\left(\mathrm{BC}_{1} \mathrm{a}\right.$ and $\left.\mathrm{BC}_{1} \mathrm{~d}\right)$ or even earlier $\left(\mathrm{BC}_{1} \mathrm{~b}\right.$ and $\mathrm{BC}_{1} \mathrm{c}$ ) than their corresponding annual parents (Fig. 5). For both $\mathrm{F}_{2}$ families, a shorter cycle was observed when the sowing date was delayed (Fig. 6).

\section{Discussion}

Segregation patterns of the $\mathrm{F}_{2}$ and $\mathrm{BC}$ progenies confirmed a strong dominance for annual habit. Dominance of the earlyflowering habit was clearly demonstrated by the $F_{1}$ families in both years, and by the segregation patterns of the $\mathrm{BC}$ and $\mathrm{F}_{2}$ families in the second year. This does not agree with Wijnheijmer et al. (1989), who suggested that biennial behavior was dominant, although these authors were working with both wild (D. carota ssp. carota) and cultivated carrots, and they did not study crosses between them. It does, however, agree with preliminary observations of Dickson (1958), who supported the hypothesis that annual flowering is dominant over biennial flowering, although his evidence was inconclusive.

Segregation of $\mathrm{F}_{2}$ families and $\mathrm{BC}_{1} \mathrm{P} 2$ could be explained by the action of a single gene. Differences between the two lateflowering parents could be the result of allelic differences or action of other genes.

Variation in the vernalization requirement has been observed since domesticated carrots arrive in Europe from Arab countries in the 13th or 14th century (Banga, 1957). Earlyflowering carrot cultivars are grown in warm temperatures and subtropical production areas of South America and Asia today (Simon et al., in press). Because flowering is an important adaptive characteristic for carrot root and seed production, understanding the genetics of this trait is valuable for breeding programs. For example, introgression of genes between annual and biennial forms will broaden the genetic base of each group,

Table 3. Observed and expected segregation ratios for flowering rate in carrot populations under the hypothesis that early flowering is dominant and monogenic.

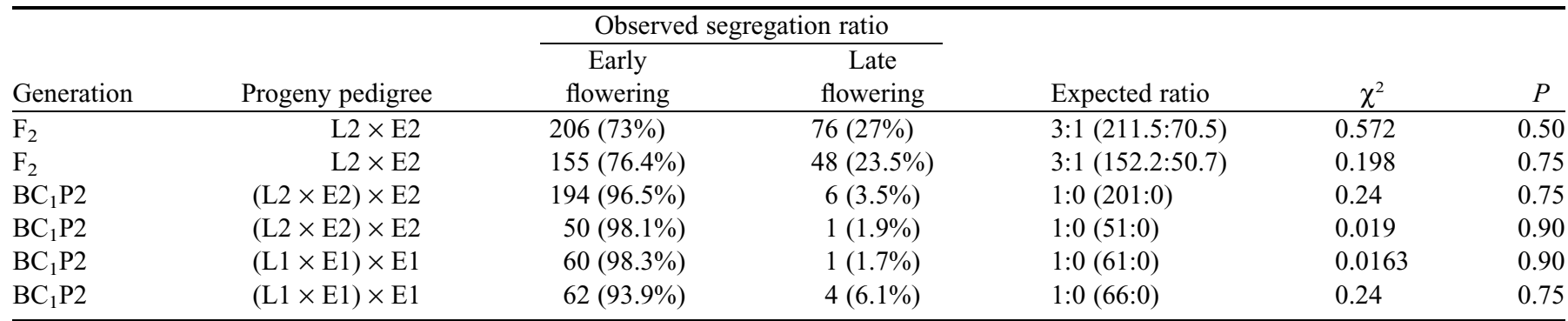

Segregating generations were derived from the crosses L2 $\times$ E2 and L1 $\times$ E1 (L1 and L2, late-flowering parents; E1 and E2 , early-flowering parents). Plants where grown in the field in La Consulta, Mendoza, Argentina. The sowing date was 4 May 2005. P2, early-flowering parent. 

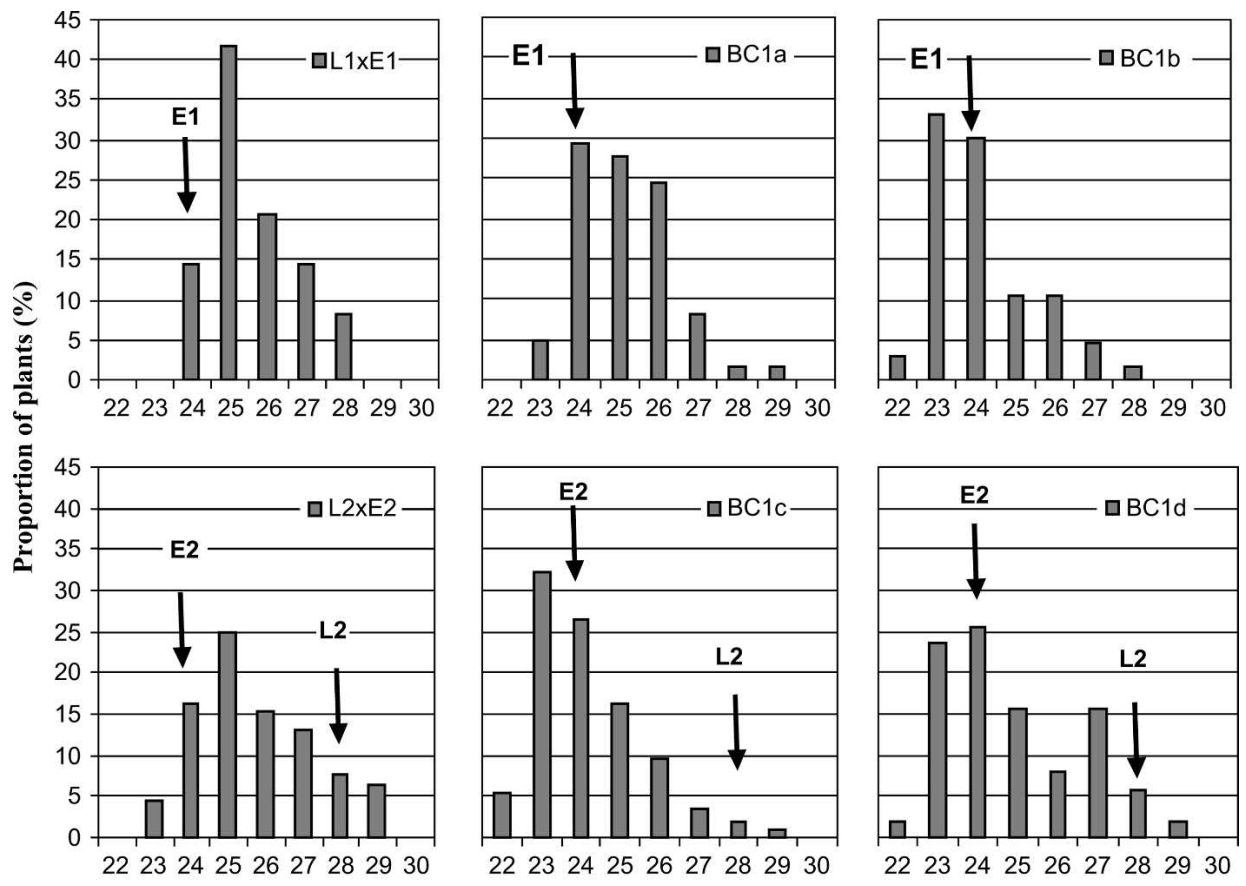

$22 \quad 2324252627282930$

$22 \quad 23242526 \quad 27282930$

Time from sowing (weeks)

Fig. 5. Proportion of carrot plants bolting for $\mathrm{F}_{1}[\mathrm{~L} 1 \times \mathrm{E} 1, \mathrm{~L} 2 \times \mathrm{E} 2(\mathrm{~L} 1$ and $\mathrm{L} 2$, late-flowering parents; $\mathrm{E} 1$ and $\mathrm{E} 2$, early-flowering parents)] and backcrosses to annual parent families $\left(\mathrm{BC}_{1} \mathrm{a}, \mathrm{BC}_{1} \mathrm{~b}, \mathrm{BC}_{1} \mathrm{c}\right.$, and $\left.\mathrm{BC}_{1} \mathrm{~d}\right)$. The number of weeks from sowing date (4 May 2005) to evaluation date are presented on the $\mathrm{x}$-axis. Weeks when the highest proportion of plants bolted for each parent (E1, E2, and L2) are represented by arrows. Because it did not flower, the L1 parent is not shown. Only $12 \%$ of L2 plants flowered.
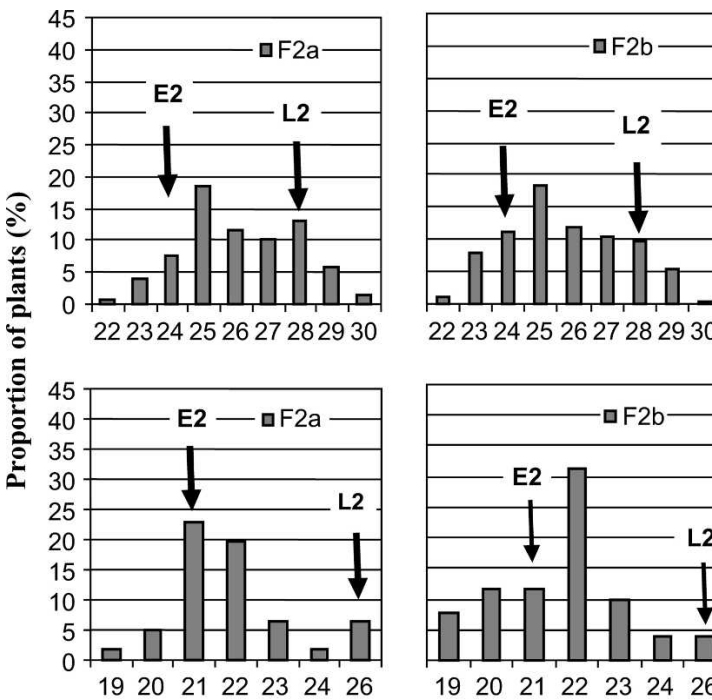

4 May 2005

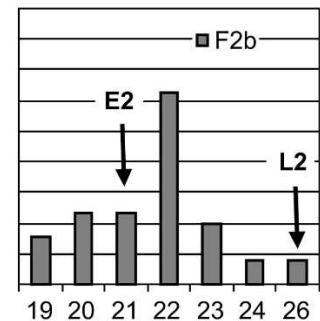

Time from sowing (weeks)

Fig. 6. Proportion of carrot plants bolting in each weekly evaluation for $\mathrm{F}_{2}$ families in the first (4 May 2005) and second (14 June 2005) sowing dates. Weeks from sowing to evaluation date are presented on the $\mathrm{x}$-axis. Dates when the highest concentration of plants bolted for each progenitor (E2 and L2) are represented by arrows. Only $12 \%$ and $6 \%$ of total L 2 plants flowered during the first and second sowing dates respectively. E2, early-flowering parent; L2, late-flowering parent.

allowing exploitation of a heterotic effects that might occur. Our observations indicate that evaluation and, consequently, selection of flowering habit depends strongly on planting time and growing conditions.

\section{Literature Cited}

Astorquizaga, R., M.S. Alessandro, and C.R. Galmarini. 2004. Efecto de la fecha de siembra en la producción de semillas de zanahoria en el Valle de Uco. Hort. Argentina 23:69 (abstr.).

Atherton, J.G. and E.A. Basher. 1984. The effects of photoperiod on flowering in carrot. J. Hort. Sci. 59:213-215.

Atherton, J.G., J. Craigon, and E.A. Basher. 1990. Flowering and bolting in carrot. I. Juvenility, cardinal temperatures and thermal times for vernalization. J. Hort. Sci. 65:423-429.

Bagget, J.R. and D. Kean. 1989. Inheritance of annual flowering in Brassica olereacea. HortScience 24:662-664.

Banga, O. 1957. The development of the original European carrot material. Euphytica 6:64-76.

Dias Tagliacozzo, G.M. and I.F.M. Valio. 1994. Effect of vernalization on flowering of Daucus carota (cvs Nantes and Brasilia). Rev. Bras. Fisiol. Vegetal 6:71-73.

Dickson, M.H. 1958. The physiology and inheritance of flowering in carrots. Michigan State University, East Lansing, MI, PhD Diss.

Dickson, M.H. and C.E. Peterson. 1958. Hastening greenhouse seed production for carrot breeding. Proc. Amer. Soc. Hort. Sci. 71:412415.

Ferreira, M.E., J. Satagopan, B.S. Yandell, P.H. Williams, and T.C. Osborn. 1995. Mapping loci controlling vernalization requirement and flowering time in Brassica napus. Theor. Appl. Genet. 90:727732.

Galmarini, C.R., R. Borgo, and R. Tizio. 1992. Determination of a prevernalization phase in carrot (Daucus carota L.) cv. Flakkee. Turrialba 42:140-142.

Galmarini, C.R. and P. Della Gaspera. 1996. Determinación de requerimientos de pre-vernalización en zanahorias (Daucus carota L.) anuales, p. 82. Actas de la XXI Reunión Argentina de Fisiología Vegetal, Mendoza, Argentina. 
Hiller, L.K. and W.C. Kelly. 1979. Post-vernalization temperature effects on seedstalk elongation and flowering in carrots, Daucus carota L. J. Amer. Soc. Hort. Sci. 104:253-257.

Lona, J.L. and J. Crnko. 1967. Floración prematura en zanahoria en las condiciones de La Consulta en relación a la producción de semillas. Mimeografiado, Estación Experimental Agropecuaria La Consulta, Instituto Nacional de Tecnología Agropecuaria, Mendoza, Argentina.

Oliva, R. 1987. Manual de producción de semillas hortícolas. Zanahoria. Publicación de la Asociación Cooperadora de la Estación Experimental Agropecuaria La Consulta, Instituto Nacional de Tecnología Agropecuaria, Mendoza, Argentina.

Rubatzky, V.E., C.F. Quiros, and P.W. Simon. 1999. Carrots and related vegetable umbelliferae. CABI Publishing, New York.
Sakr, E.S. and H.C. Thompson. 1942. Effect of temperature and photoperiod on seedstalk development in carrots. Proc. Amer. Soc. Hort. Sci. 41:343-346.

Simon, P.W., R.E. Freeman, J.V. Vieira, L.S. Boiteux, M. Briard, T. Nothnagel, B. Michalik, and Y.S. Kwon. (in press). Carrot breeding. In: J. Prohens, M.J. Carena, and F. Nuez (eds.). Handbook of crop breeding. Vol. 1, Vegetable breeding. Springer-Verlag, Heidelberg, Germany.

Walkof, C. 1963. A mutant annual cabbage. Euphytica 12:77-80.

Whitaker, T.W., A.F. Sherf, W.H. Lange, C.W. Nicklow, and J.D. Radewald. 1970. Carrot production in the United States. Agr. hdbk. no. 375, Agr. Res. Serv., U.S. Dept. Agr., Washington DC.

Wijnheijmer, E.H.M., W.A. Brandenburg, and S.J. Ter Borg. 1989. Interactions between wild and cultivated carrots (Daucus carota L.) in the Netherlands. Euphytica 40:147-154. 